\title{
Comparative study of pharmacological and combined pharmaco- mechanical method of induction of labour: a randomised study
}

\author{
Anshu Kumari ${ }^{1}$, Mahantappa A. Chiniwar ${ }^{1 *}$, Sharada B. Menasinkai ${ }^{2}$ \\ ${ }^{1}$ Department of Obstetrics and Gynecology, ${ }^{2}$ Department of Anatomy, Adichunchanagiri Institute of Medical Sciences \\ and Research Hospital affiliated to Adichunchanagiri University (ACU) B G Nagara, Nagamangala Mandya, \\ Karnataka, India
}

Received: 10 March 2021

Accepted: 09 April 2021

\section{*Correspondence:}

Dr. Mahantappa A. Chiniwar,

E-mail: drmachiniwar@gmai.com

Copyright: (c) the author(s), publisher and licensee Medip Academy. This is an open-access article distributed under the terms of the Creative Commons Attribution Non-Commercial License, which permits unrestricted non-commercial use, distribution, and reproduction in any medium, provided the original work is properly cited.

\begin{abstract}
Background: Comparative study of Pharmacological and Pharmaco- Mechanical method of induction of labour- A Randomised study. The objective of the study was to compare efficacy of pharmacological and combined pharmacomechanical method of induction of labour.

Methods: A study was conducted in the department of Obstetrics and gynaecology, Adichunchanagiri Institute of Medical Sciences and Research Centre for a period of 18 months. 200 pregnant women requiring induction of labour were included in the study. In group 1 Dinoprostone $0.5 \mathrm{mg}$ gel was inserted into cervical canal. In group 2 Foley's catheter No $18 \mathrm{~F}$ was inserted within the cervix. The balloon of the catheter was filled with $30 \mathrm{ml}$ normal saline and at the same time Dinoprostone $0.5 \mathrm{mg}$ gel was inserted into posterior vaginal fornix. The Excel and SPSS (SPSS Inc, Chicago V 18.5) software packages were used for data entry and analysis. The results were averaged (mean \pm Std Deviation) for each parameter for continuous data in tables.

Results: Mean induction to active phase interval in group 1 was $8.43 \pm 4.11 \mathrm{hrs}$, in group $26.82 \pm 3.01 \mathrm{hrs}(\mathrm{p}=0.001)$. The rate of vaginal delivery in group 1 and group 2 was $55 \%$ and $66 \%$ respectively, difference was statistically significant $(\mathrm{p}=0.026)$.

Conclusions: Synchronous use of intracervical Foley's catheter and Dinoprostone $0.5 \mathrm{mg}$ resulted in a shorter time for progress to active phase and also shortened induction to delivery interval as compared to Dinoprostone $0.5 \mathrm{mg}$ alone. Higher risk of caesarean delivery was associated with single method as compared to combined methods.
\end{abstract}

Keywords: Caesarean delivery, Induction of labour, IUGR

\section{INTRODUCTION}

Induction of labour can be defined as the artificial initiation of labour before it's spontaneous onset, for the purpose of delivery of feto-placental unit. There are two categories of artificial means of cervical ripening prior to labour induction - mechanical (Foley's catheter, Laminaria tent), and pharmacological (PGE1, PGE2, PGF2, Alpha oestrogen). Mechanical devise dilate the cervix by accessing the fetal membranes, and pharmacological preparations cause connective tissue softening cervix effacement and uterine activity. ${ }^{1}$
Labour induction is usually performed when the risks of continuing pregnancy are more than the benefits of delivery.

Indications include immediate conditions such as severe eclampsia or ruptured membranes with choreo-amnitis. The other common medical and obstetric indications include membrane rupture without labour, gestational hypertension, post-dated pregnancy, oligohydramnios, non-reassuring fetal status, intra uterine growth restrictions (IUGR), chronic hypertension and diabetes. Ideally the agents used for induction should mimic 
spontaneous labour without causing excessive uterine activity. $^{2}$

Many women who undergo labour induction do not have favourable cervix, which can lead to a prolonged and difficult induction, so some method of cervical ripening pharmacological or mechanical - often is used. Preinduction cervical ripening is often done to increase the likelihood of successful labour induction. ${ }^{3}$

Both mechanical and pharmacological methods are used for induction of labour. These agents when used individually reduce the incidence of caesarean delivery in women undergoing induction. Possibly combining both mechanical and pharmacological methods may have a synergistic effect in achieving labour. Some studies have shown promise in reducing labour time and risks of caesarean delivery with combination methods while others have not. ${ }^{4}$

$20 \%$ of all deliveries are initiated this method, undoubtedly cervical ripening has a close relationship with the success rate of delivery. Induction of labour with oxytocin in presence of low Bishop score, may not lead to vaginal delivery in a suitable period of time and also is followed by increased rate of caesarean deliveries.

Hence of methods of cervical ripening that ripens the cervix in a short period of time play an important role in modern obstetrics. Cervical Foley's catheter and vaginal Misoprostal (PGE1) are used for labour induction and cervical ripening. Since Misoprostal is relatively cheap, stable at room temp and has good effect, it is frequently used in obstetrics for termination of pregnancy especially 3rd trimester. ${ }^{5}$

Over the past 2 decades there has been an abrupt increase in labour induction rate, for variety of indications including hypertensive disorders, post-dated pregnancy, intrauterine growth restrictions and elective reasons from $9.5 \%$ in 1990 to $21.2 \%$ in 2004.An unripe cervix is a major impediment for the success of labour induction, the status of which can be determined by the Bishop pelvic scoring system. A low Bishop score in induced labour is associated with a high risk of caesarean delivery. A variety of pharmacological and mechanical methods have been developed to ripen the unfavourable cervix. One of the mechanical method used is Foley's catheter. Mechanical methods exert local pressure on the cervix, overstretching the lower uterine segment and indirectly stimulate the secretion of Prostaglandins. The Foley's catheter versus vaginal Prostaglandins E2 gel for induction of labour at term with an unfavourable cervix, induction of labour with Foley's catheter was equally effective as Prostaglandin with less morbidity, but longer time of delivery. ${ }^{6}$ The present study was done to compare efficacy of pharmacological and combined pharmacomechanical method of induction of labour. Outcome measures were induction to delivery time, mode of delivery and neonatal outcome.

\section{METHODS}

A Randomised study was conducted in the department of Obstetrics and gynaecology, Adichunchanagiri Institute of Medical Sciences and Research Hospital B G Nagara for a period of 18 months from Nov 2017 to May 2019. 200 pregnant women requiring induction of labour were included in the study.

\section{Inclusion criteria}

Women with gestational age $\geq 37$ wks, singleton pregnancy with cephalic presentation, intact membranes and Bishop score $\leq 5$ and those who had obstetric indication for induction of labour.

\section{Exclusion criteria}

Women with multiple pregnancy, fetal demise, anomalous baby, fetal mal-presentation, previous uterine surgery and those who had contraindications for vaginal delivery.

After proper written consent, detailed history regarding maternal age, gestational age, parity, were noted down. General physical examination, systemic and obstetric examination including per vaginal examination to assess the Bishop score was done. All the baseline investigations were done.

All the patients were allocated in to 2 groups. In group 1 Dinoprostone $0.5 \mathrm{mg}$ gel was inserted into cervical canal and the patient was reassessed after $6 \mathrm{hrs}$. In group 2 Foley's catheter No $18 \mathrm{~F}$ was inserted within the cervix (extra amniotic) with all aseptic precautions. The balloon of the catheter was filled with $30 \mathrm{ml}$ normal saline and catheter pulled so that bulb rests on internal os of cervix and at the same time Dinoprostone $0.5 \mathrm{mg}$ gel was inserted into posterior vaginal fornix. Patients were reassessed after $6 \mathrm{hrs}$ and the cases with no regular uterine contractions and cervical changes, second dose of Dinoprostone $0.5 \mathrm{mg}$ gel was administered. Maximum 3 dosed were administered. Subsequent dose was withheld for patients with active labour, cervical effacement > $60 \%$ and cervical os dilatation $>3 \mathrm{~cm}$. Augmentation of labour was done as per labour room protocol for required cases.

Caesarean delivery was decided for women who failed to progress. Failure to progress was decided as two hrs after active phase ( 3-4 contractions per 10 minutes lasting for 10- 45 seconds, cervical dilatation $>3 \mathrm{~cm}$, and effacement $>80 \%$ ), or no descent of head after $1 \mathrm{hr}$ of full dilatation in spite of good uterine contractions. The outcome was measured as induction delivery interval and mode of delivery.

The Excel and SPSS (SPSS Inc, Chicago V 18.5) software packages were used for data entry and analysis. 
The results were averaged (mean \pm Std Deviation) for each parameter for continuous data in tables.

\section{RESULTS}

Maximum numbers of women were in the age group of $21-25$ yrs. $48 \%$ in group 1 and $51 \%$ in group 2 women belonged to gestational age $40-40+6$ wks. Term gestation was the major indication for induction of labour. Intracervical Dinoprostan gel was used for $63 \%$ and Foley's catheter with Dinoprostone gel was used for $74 \%$ of women with term gestation. Second common group indication was women with gestational hypertension and in 21\% Dinoprostone gel was used and in 9\% Foley's catheter with Dinoprostone gel was used.

Vaginal delivery was conducted $55 \%$ in group 1 and $66 \%$ in group 2 ( $\mathrm{p}=0.026)$. Emergency LSCS was done for $45 \%$ women in group 1 and $34 \%$ women in group 2 . Failure to progress was the indication for $64.44 \%$ in group 1 and $67.64 \%$ in group 2 women. Fetal distress was the indication for $31.11 \%$ in group 1 and $32.35 \%$ in group 2. Secondary arrest of descent was the indication in $4.44 \%$ in group 1 and no cases in group 2 .

Table 1: Comparison of indication for induction of labour in both groups.

\begin{tabular}{|c|c|c|c|c|c|c|}
\hline \multirow[t]{3}{*}{ Indications for induction of labour } & \multicolumn{4}{|c|}{ Group } & \multicolumn{2}{|c|}{ Total } \\
\hline & \multicolumn{2}{|c|}{ Group 1} & \multicolumn{2}{|c|}{ Group 2} & \multirow[b]{2}{*}{$\mathbf{N}$} & \multirow[b]{2}{*}{$\%$} \\
\hline & $\mathbf{N}$ & $\%$ & $\mathbf{N}$ & $\%$ & & \\
\hline Term gestation & 63 & 63 & 74 & 74 & 137 & 68.5 \\
\hline Gestational hypertension & 21 & 21 & 9 & 9 & 30 & 15.0 \\
\hline GDM & 4 & 4 & 1 & 1 & 5 & 2.5 \\
\hline Decreased PFM & 4 & 4 & 1 & 1 & 5 & 2.5 \\
\hline Pre- eclampsia & 3 & 3 & 1 & 1 & 4 & 2.0 \\
\hline RH Negative & 3 & 3 & 2 & 2 & 5 & 2.5 \\
\hline Oligohydramnios & 1 & 1 & 8 & 8 & 9 & 4.5 \\
\hline IUGR & 1 & 1 & 0 & 0 & 1 & 0.5 \\
\hline Oligohydramnios with IUGR & 0 & 0 & 2 & 2 & 2 & 1.0 \\
\hline Chronic hypertension & 0 & 0 & 1 & 1 & 1 & 0.5 \\
\hline Chronic hypertension & 0 & 0 & 1 & 1 & 1 & 0.5 \\
\hline Total & 100 & 100 & 100 & 100 & 200 & 100 \\
\hline
\end{tabular}

Table 2: Comparison of induction to delivery interval in both groups.

\begin{tabular}{|c|c|c|c|c|}
\hline \multirow[t]{2}{*}{ Time duration } & \multicolumn{2}{|l|}{ Group 1} & \multicolumn{2}{|l|}{ Group 2} \\
\hline & Primigravida & Multigravida & Primigravida & Multigravida \\
\hline$<6 \mathrm{hrs}$ & $1(1.81 \%)$ & $0(0 \%)$ & $1(1.51 \%)$ & $1(1.51 \%)$ \\
\hline $6-10$ hrs & $11(20.0 \%)$ & $9(16.36 \%)$ & $24(36.36 \%)$ & $18(27.27 \%)$ \\
\hline $11-15$ hrs & $15(27.27 \%)$ & $10(18.18 \%)$ & $10(15.15 \%)$ & $5(7.57 \%)$ \\
\hline $16-20 \mathrm{hrs}$ & $7(12.73 \%)$ & $1(1.81 \%)$ & $3(4.55 \%)$ & $1(1.51 \%)$ \\
\hline $21-25$ hrs & $0(0 \%)$ & $0(0 \%)$ & $2(3.03 \%)$ & $1(1.51 \%)$ \\
\hline $26-30 \mathrm{hrs}$ & $0(0 \%)$ & $0(0 \%)$ & $0(0 \%)$ & $0(0 \%)$ \\
\hline $31-35$ hrs & $0(0 \%)$ & $01(1.81 \%)$ & $0(0 \%)$ & $0(0 \%)$ \\
\hline & 34 & 21 & 40 & 26 \\
\hline
\end{tabular}

Table 3: Neonatal outcome.

\begin{tabular}{|llll|}
\hline Fetal outcome & Group 1 & Group 2 & P value \\
\hline Baby weight & $3.085 \pm 0.371$ & $2.943 \pm 0.378$ & 0.008 \\
\hline APGAR score at $\mathbf{1}$ mt & $6.64 \pm 0.81$ & $6.81 \pm 0.486$ & 0.07 \\
\hline APGAR score at 5 mt & $8.76 \pm 0.0683$ & $8.83 \pm 0.472$ & 0.40 \\
\hline
\end{tabular}

Induction to delivery interval was variable in primigravida and multigravida. 34 primigravida delivered within $20 \mathrm{hrs}$ in group 1 and 38 delivered within $20 \mathrm{hrs}$ in group 2. Among the multigravida 30 in group 1 and 25 in group 2 delivered within $20 \mathrm{hrs}$ of induction. 


\section{DISCUSSION}

The present study was done to compare the efficacy of pharmacological and combined pharmaco - mechanical method of induction of labour. All the patients were allocated in to 2 groups. In group 1 Dinoprostone $0.5 \mathrm{mg}$ gel was inserted into cervical canal and in group 2 Foley's catheter No $18 \mathrm{~F}$ and at the same time Dinoprostan $0.5 \mathrm{mg}$ gel was inserted to posterior vaginal fornix.

Gestational age in the present study was $40+$ wks in $48 \%$ in group 1 and $51 \%$ in group 2 and is comparable with study reported by Fatemeh $\mathrm{V}$ et al. $^{5}$ According to their study 108 women selected for induction of labour, Misoprostal vaginal tab was inserted to 49 cases of group 1 and intra-cervical Foley's catheter was used for 59 women of group 2.The gestational age was $39.8 \pm 1.4$ wks in group 1 and $40 \pm 0.9$ wks in group 2. Sunita $\mathrm{M}$ et al reported a study of 140 women selected for induction of labour, PGE2 gel was inserted intra-cervically for 70 women and Foley's catheter with bulb filled with $50 \mathrm{ml}$ saline for 70 women. $^{7} 40+$ wks of gestation was seen in
$32.9 \%$ in PGE2 group and $31.5 \%$ in Foley's catheter group.

Priyanka et al reported a study of 100 women, Misoprostal vaginal tab was used for 50 women and in 50 women Foley's catheter was used for induction of labour. ${ }^{8}$ Nasareen $\mathrm{N}$ et al reported a study of 104 women selected for induction of labour, vaginal Misoprostal was used for 60 women and Foley's catheter was used in 44 women. ${ }^{2}$

Following table shows oligohydramnios was the common indication in both studies whereas in the present study only in $9 \%$ of cases. In the present study indication for induction was mainly for term gestation, $63 \%$ in group 1 and $74 \%$ in group 2 .

Kenneth $\mathrm{G}$ et al reported a study of 65 cases (group A) with Foley's catheter with intra cervical gel and 62 cases with vaginal Misoprostal. ${ }^{10}$ Women with Pre-eclampsia and post dated pregnancy were major indications for induction of labour in both A and B groups.

Table 4: Comparison of indications for induction of labour with other studies.

\begin{tabular}{|c|c|c|c|c|c|c|c|c|}
\hline \multirow[t]{2}{*}{ Indications } & \multicolumn{2}{|c|}{ Nasareen $\mathrm{N}$ et $\mathrm{al}^{2}$} & \multicolumn{2}{|c|}{ 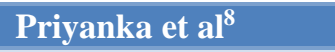 } & \multicolumn{2}{|c|}{ Kenneth $\mathbf{G}$ et al ${ }^{10}$} & \multicolumn{2}{|l|}{ Present study } \\
\hline & $\begin{array}{l}\text { Misoprastal } \\
\mathrm{N}=60\end{array}$ & $\begin{array}{l}\text { Foley's } \\
\mathrm{N}=44\end{array}$ & $\begin{array}{l}\text { Misoprostal } \\
\mathbf{N}=\mathbf{5 0}\end{array}$ & $\begin{array}{l}\text { Foley's } \\
\mathbf{N}=\mathbf{5 0}\end{array}$ & $\begin{array}{l}\text { Misoprostal } \\
\mathrm{N}=62\end{array}$ & $\begin{array}{l}\text { Foley's } \\
\mathrm{N}=65\end{array}$ & $\begin{array}{l}\text { Dinoprostal } \\
\mathrm{N}=100\end{array}$ & $\begin{array}{l}\text { Foley's } \\
\mathrm{N}=100\end{array}$ \\
\hline $\begin{array}{l}\text { Oligohydra- } \\
\text { mnios }\end{array}$ & $11(18.3 \%)$ & $8(18.2 \%)$ & 42 & 48 & $4(7 \%)$ & $6(9 \%)$ & $1(1 \%)$ & $8(8 \%)$ \\
\hline $\begin{array}{l}\text { Pre- } \\
\text { eclampsia }\end{array}$ & $11(18.3 \%)$ & $4(9.1 \%)$ & - & - & $26(41 \%)$ & $28(43 \%)$ & $3(3 \%)$ & $1(1 \%)$ \\
\hline IUGR & $7(11.7 \%)$ & $4(9.1 \%)$ & - & - & $4(7 \%)$ & $7(11 \%)$ & $1(1 \%)$ & 0 \\
\hline GDM & $2(3.4 \%)$ & $1(2.3 \%)$ & - & - & - & - & $4(4 \%)$ & $1(1 \%)$ \\
\hline Postdated & - & - & 30 & 28 & $12(20 \%)$ & $15(22 \%)$ & - & - \\
\hline
\end{tabular}

Table 5: Comparison of Bishop score with other studies.

\begin{tabular}{|c|c|c|c|c|c|c|c|c|}
\hline Bishop score & \multicolumn{2}{|c|}{ Gayatri $\mathbf{M}$ et al $^{\mathbf{1}}$} & \multicolumn{2}{|c|}{ Sabiha $\mathbf{N}$ et $\mathbf{a l}^{\mathbf{3}}$} & \multicolumn{2}{|c|}{ Nasareen $\mathbf{N}$ et $\mathrm{al}^{2}$} & \multicolumn{2}{|c|}{ Present study } \\
\hline & Dinopro gel & Foley's & misoprostal & Foley's & Mesoprostal & Foleys & Prost gel & Foley's \\
\hline Initial & $2.26 \pm 0.76$ & $2.34 \pm 0.81$ & $3.7 \pm 2.2$ & $7.3 \pm 3.0$ & - & - & $4.1 \pm 0.68$ & $4.2 \pm 0.73$ \\
\hline After $>6$ hrs & $8.34 \pm 2.13$ & $7.66 \pm 1.74$ & - & - & - & -- & $6.1 \pm 1.24$ & $6.5 \pm 1.31$ \\
\hline $\begin{array}{l}\text { Induction } \\
\text { to active phase }\end{array}$ & $8.58 \pm .11$ & $7.45 \pm 3.41$ & $8.9 \pm 3.8$ & $12.0 \pm 4.5$ & $11.6 \pm 5.21$ & $11.8 \pm 5.82$ & - & - \\
\hline $\begin{array}{l}\text { Duration from } \\
\text { ripening to } \\
\text { delivery }\end{array}$ & $5.78 \pm 2.59$ & $6.86 \pm 4.37$ & $9.2 \pm 4.1$ & $9.2 \pm 4.1$ & $14.03 \pm 7.61$ & $18.40 \pm 8.2$ & - & - \\
\hline
\end{tabular}

In the present study there was slight improvement in Bishop score after 6 hrs in both the groups. According to a study reported by Sunita $M$ et al Bishop score was $1.48 \pm 0.82$ in PGE2 group and $1.74 \pm 0.27$ in Foley's catheter group. ${ }^{7}$ Ruchika Garg et al reported a randomized controlled study of 50 cases with Foley's catheter + PGE2 (group A) and 50 cases with $0.5 \mathrm{mg}$ Dinoprostan gel (group B). ${ }^{9}$ The mean primary Bishop score in group A was $1.80 \pm 0.40$ and in group B was $16.64 \pm 0.48$ The mean post induction Bishop score was $7.16 \pm 0.37$ in group $\mathrm{A}$ and $6.80 \pm 0.50$ in group $\mathrm{B}$ ( $\mathrm{P}$ value $0.0001)$. 
In the present study induction to delivery interval was variable in primigravida and multigravida.34 primigravida delivered within $20 \mathrm{hrs}$ in group 1 and 38 delivered within $20 \mathrm{hrs}$ in group 2. Among the multigravida 30 in group 1 and 25 in group 2 delivered within $20 \mathrm{hrs}$ of induction. Sabiha N et al reported a comparative study of intravaginal Misoprostal in 50 cases
(Group 1) versus Foley's catheter 49 cases (Group 2). ${ }^{3}$ Pre-induction to delivery interval was $3.7 \pm 2.2$ to $9.2 \pm 4.1$ in group 1 and $7.3 \pm 3.0$ to $14.8 \pm 5.2$ in group 2. According to Priyanka et al postdated women took more time, 10.46 hrs in Misoprostal group and $20.56 \mathrm{hrs}$ in Foley's catheter group whereas $10.36 \mathrm{hrs}$ in Misoprostal group and 16.52 hrs in Foley's catheter group. ${ }^{8}$

Table 6: Comparison of mode of delivery with other studies.

\begin{tabular}{|c|c|c|c|c|}
\hline Study & $\begin{array}{l}\text { Method used for induction of } \\
\text { labour }\end{array}$ & Vaginal delivery & $\begin{array}{l}\text { Caesarean } \\
\text { delivery }\end{array}$ & $P$ value \\
\hline \multirow{2}{*}{ Gayatri $M$ et al ${ }^{1} N=300$} & Gr $1-\mathrm{N} 150$ & $138(92 \%)$ & $12(8 \%)$ & 0.0001 \\
\hline & Gr 2 - N 150 & $119(79.3 \%)$ & $31(20.66)$ & \\
\hline \multirow{2}{*}{$\begin{array}{l}\text { Sabiha } \mathrm{N} \text { et } \mathrm{al}^{3} \\
\mathrm{~N}=99\end{array}$} & Gr 1 - N 50 & $32(64 \%)$ & $18(36 \%)$ & \\
\hline & Gr 2 - N 49 & $44(89.8 \%)$ & $5(10.2 \%)$ & \\
\hline \multirow{2}{*}{ Fatemeh $\mathrm{V}$ et $\mathrm{al}^{5} \mathrm{~N}=108$} & Gr 1 - N 49 & $44(89.9 \%)$ & $5(10.2 \%)$ & \\
\hline & Gr 2 - N 59 & $37(62.7 \%)$ & $22(37.3 \%)$ & \\
\hline \multirow{2}{*}{ Sunita $M$ et al $^{7} N=140$} & Gr 1 - N 70 & $52(81.4 \%)$ & $13(18.6 \%)$ & \\
\hline & Gr $2-\mathrm{N} 70$ & $43(84.3 \%)$ & $7(15.7 \%)$ & \\
\hline \multirow{2}{*}{ Priyanka et al ${ }^{8} N=100$} & Gr 1 - N 50 & $61.5 \%$ & $37.5 \%$ & \\
\hline & Gr 2 - N 50 & $38.5 \%$ & $62.5 \%$ & \\
\hline \multirow{2}{*}{ Nasareen $\mathrm{N}$ et $\mathrm{al}^{2} \mathrm{~N}=104$} & Gr 1 - N 60 & $46(76.7 \%)$ & $14(23.3 \%)$ & \\
\hline & Gr $2-\mathrm{N} 44$ & $25(56.8 \%)$ & $19(43.2 \%)$ & 0.0001 \\
\hline \multirow{2}{*}{ Ruchika Garg et al $^{9}$} & Gr 1- N 50 (B) & $32(64 \%)$ & $18(36 \%)$ & \\
\hline & Gr 2 - N 50 (A) & $35(70 \%)$ & $15(30 \%)$ & \\
\hline \multirow[t]{2}{*}{ Kenneth G et al ${ }^{10}$} & Gr 1 - N 62 & $48(77 \%)$ & $14(23 \%)$ & \\
\hline & Gr 2 - N 65 & $49(75 \%)$ & $16(25 \%)$ & NS \\
\hline \multirow{2}{*}{ Present study } & Gr $1-\mathrm{N} 100$ & $55(55 \%)$ & $45(45 \%)$ & \\
\hline & Gr $2-\mathrm{N} 100$ & $66(66 \%)$ & $34(34 \%)$ & 0.026 \\
\hline
\end{tabular}

Group 1 Pharmacological method. Group 2 Foley's catheter used for induction of labour

Table 7: Comparison of neonatal outcome with other studies.

\begin{tabular}{|c|c|c|c|c|c|c|}
\hline \multirow[t]{2}{*}{ Neonatal outcome } & \multicolumn{2}{|c|}{ Fatemeh V et $\mathbf{a l}^{5}$ study } & \multicolumn{2}{|c|}{ Nasareen $\mathbf{N}$ et $\mathbf{a l}^{2}$} & \multicolumn{2}{|c|}{ Present study } \\
\hline & $\begin{array}{l}\text { Misoprostal } \\
\mathrm{N}=49\end{array}$ & $\begin{array}{l}\text { Foley's } \\
\text { N=59 }\end{array}$ & $\begin{array}{l}\text { Misoprostal } \\
\mathbf{N}=\mathbf{6 0}\end{array}$ & $\begin{array}{l}\text { Foley's } \\
\text { N=44 }\end{array}$ & $\begin{array}{l}\text { Prostodine } \\
\mathrm{N}=100\end{array}$ & $\begin{array}{l}\text { Foley's } \\
\text { N=100 }\end{array}$ \\
\hline Birth wt & $3182 \pm 43$ & $3323.8 \pm 353$ & $2790 \pm 43$ & $2910 \pm 53$ & $3085 \pm 0.37$ & $2943 \pm 0.378$ \\
\hline APGAR score at $1 \mathrm{mt}$ & 8 & 8 & $7.8 \pm 0.77$ & $7.91 \pm 0.33$ & $6.64 \pm 0.81$ & $6.81 \pm 0.486$ \\
\hline APGAR score at $5 \mathrm{mt}$ & 9 & 9 & $8.92 \pm 0.38$ & $8.98 \pm 0.15$ & $8.76 \pm 0.683$ & $8.83 \pm 0.472$ \\
\hline
\end{tabular}

APGAR score at the end of 1 minute is less in present study compared to study reported by Fate et al and Nasareen $\mathrm{N}$ et al and is comparable to these studies at the end of 5 minutes. ${ }^{5,2}$

Gayatri $\mathrm{M}$ et al reported a study of 300 women selected for induction of labour. ${ }^{1} 150$ women were used PGE2 gel (group 1) and Foley's catheter was used for 150 cases (group 2). \% of caesarean delivery was more in group 2. Indication for caesarean delivery was non-reassuring FHS in 6 cases in group 1 and 6 cases in group 2. Failed induction was another indication in 6 cases in group 1 and 24 cases in group 2.

According to a study reported by Sabiha $\mathrm{N}$ et al \% of vaginal delivery was $64 \%$ in group 1 and $89.8 \%$ in group
2. And $36 \%$ in group 1 and $10.2 \%$ in group 2 required caesarean delivery. ${ }^{3}$

Vaginal delivery $\%$ is more in pharmacological method group in all these studies compared to mechanical group. In the present study 55\% in Pharmacological group and $66 \%$ in combination of pharmaco-mechanical group had vaginal delivery.

According to study done by Sunita $\mathrm{M}$ et al $84.3 \%$ in PGE2 group and $81.4 \%$ in Foley's catheter group had vaginal delivery. Caesarean delivery was done for $18.6 \%$ in group 1 and $15.7 \%$ in group $2 .^{7}$

Choudhary A et al reported a study of 110 women, group 1 Foley's catheter $(\mathrm{N}=55)$ and group 2 Foley's catheter 
with PGE 2 gel $(\mathrm{N}=55)$. The $\%$ of vaginal delivery was 74.6 in group 1 and 70.9 in group $2 .{ }^{11}$ The $\%$ of caesarean delivery was 25.5 in group 1 and 29.1 in group 2 .

Judich $\mathrm{H}$ et al reported a study of 146 women where in Misoprostal alone (group 1) was used in 49 cases, Foley's catheter alone (group 2) was used in 54 cases and combination of the two (group 3 ) in 43 cases. The $\%$ of vaginal delivery was 63.3 in group 1 and 57.4 in group 2 and 58.1 in group 3. And the \% of Caesarean delivery was 36.7 in group $1,42.6$ in group 2 and 41.9 in group $3 .{ }^{12}$

\section{CONCLUSION}

Synchronous use of intracervical Foley's catheter and Dinoprostone $0.5 \mathrm{mg}$ resulted in a shorter time for progress to active phase and also shortened induction to delivery interval as compared to Dinoprostone $0.5 \mathrm{mg}$ alone.

Higher risk of caesarean delivery was associated with single method as compared to combined methods.

\section{Funding: No funding sources}

Conflict of interest: None declared

Ethical approval: The study was approved by the Institutional Ethics Committee

\section{REFERENCES}

1. Mathuriya G, Kushwaha S, Pradhan S. Comparative study of induction of labour with dinoprostone gel versus mechanical dilatation in unfavorable cervix (low Bishops Score). International J Reproduction, Contraception, Obstetrics and Gynecol. 2017;6(10):4363-6.

2. Noor N, Ansari M, Ali SM, Parveen S. Foley catheter versus vaginal misoprostol for labour induction. International journal of reproductive medicine. 2015;2015.

3. Nazneen S, Sultana F, Nahaer K. Intravaginal Mesoprostal Versus Transcervical Foley's catheter for Pre-induction cervical ripening and their outcome - A Comparative study. Bangladesh J of Obstet and Gynaecol. 2012;27(2):72-8.

4. Levine LD, Downes KL, Elovitz MA, Parry S, Sammel MD, Srinivas SK. Mechanical and Pharmacologic Methods of Labor induction: A
Randomized controlled Trial. Obstet Gynaecol 2016; 128(6):1357-64.

5. Roudsari FV, Ayati S, Ghasemi M, Mofrad MH, Shakeri MT, Farshidi F, Shahabian M. Comparison of vaginal misoprostol with foley catheter for cervical ripening and induction of labor. Iranian journal of pharmaceutical research: IJPR. 2011;10(1):149.

6. Indira $\mathrm{G}$, Latha $\mathrm{V}$, Narayanamma L. Comparative study of induction of labour with Foley. s catheter inflated to $30 \mathrm{ml}$ versus $60 \mathrm{ml}$. J Clinic Sci Res. 2016;5:153-9.

7. Murmu S, Dwivedi C. A comparative study of intracervical Foley's catheter and intracervical PGE2 gel for preinduction cervical ripening. IJRCOG. 2018;7(8):3122-5.

8. Shashi P, Bala A, Sinha M, Goel JK. A Comparative study of intracervical Foley's catheter with oxytocin and vaginal misoprostal for induction of labour. IJRCOG. 2020;9(9):3660-4.

9. Garg R, Vardhan S, Singh S, Singh R. Foley Catheter with vaginal prostaglandin E2 gel versus vaginal prostaglandin E 2 gel alone for induction of labour: a randomized controlled trial. IJRCOG. 2018; 7(5):1893-6.

10. Kenneth G, Perry Jr, J Flaine Larman, Warren L May, Lynd G, Robinette R N, BSN and Rick W Martin. Cervical ripening: A Randomised comparison between intracervical balloon catheter combined with intravaginal dinoprostone. American Journal of Obst and Gynaecol. 1998;178(9):133340 .

11. Chowdhary A, Bagga R, Kalra J, Jain V, Saha SC, Kumar P. Comparison of intracervical Foley's catheter used alone or combined with a single dose of dinoprostone gel for cervical ripening: a randomised study. J Obst and Gynaecology. 2019;39(4):461-7.

12. Chung JH, Huang WH, Rumney PJ, Garite TJ, Nageotte MP. A prospective randomized controlled trial that compared misoprostol, Foley catheter, and combination misoprostol-Foley catheter for labor induction. American J Obstetrics and Gynecol. 2003;189(4):1031-5.

Cite this article as: Kumari A, Chiniwar MA, Menasinkai SB. Comparative study of pharmacological and combined pharmacomechanical method of induction of labour: a randomised study. Int J Reprod Contracept Obstet Gynecol 2021;10:1977-82. 